Huppert, K., Perron, J. T., Ashton, A. D. (2020): The influence of wave power on bedrock sea-cliff erosion in the Hawaiian Islands. - Geology, 48, 5, 499-503.

https://doi.org/10.1130/G47113.1 


\title{
The influence of wave power on bedrock sea-cliff erosion in the Hawaiian Islands
}

\author{
Kimberly L. Huppert ${ }^{12^{*}}$, J. Taylor Perron ${ }^{1}$, and Andrew D. Ashton ${ }^{3}$ \\ ${ }^{1}$ Department of Earth, Atmospheric \& Planetary Sciences, Massachusetts Institute of Technology, Cambridge, \\ Massachusetts 02139, USA \\ ${ }^{2}$ GFZ German Research Centre for Geosciences, Potsdam 14473, Germany \\ ${ }^{3}$ Woods Hole Oceanographic Institution, Woods Hole, Massachusetts 02543, USA \\ *Email: khuppert@gfz-potsdam.de
}

CITATION: Huppert, K.L., Perron, J.T., and Ashton, A.D., 2020, The influence of wave power on bedrock sea-cliff erosion in the Hawaiian Islands: Geology, v. 48, p. 499-503, https://doi.org/10.1130/G47113.1

\section{ABSTRACT}

Waves erode sea cliffs by various mechanisms, but the influence of wave power on bedrock coastal erosion has not been well quantified, making it difficult to predict how rocky coasts evolve in different environments. Volcanic ocean islands offer a unique opportunity to examine the influence of waves on bedrock coastal erosion because many islands have relatively homogeneous bedrock, well-constrained initial topography, and considerable differences in wave power between shorelines that face different directions and wave regimes. We used lava-flow ages and the morphology of coastal profiles on Maui, Kaho'olawe, and the Big Island of Hawai'i (USA) to estimate sea-cliff retreat rates at 11 sites that experience nearly eightfold differences in incident wave power. Using a range of possible sea-level histories that incorporate different trends of subsidence due to volcanic loading, we modeled the evolution of each coastal profile since its formation (12 ka to $1.4 \mathrm{Ma}$ ) to find the regionally consistent relative sea-level history and the site-specific sea-cliff retreat rates that best repro- duce observed coastal profiles. We found a best-fit relative sea-level history prescribed by an effective elastic lithosphere thickness of $30 \mathrm{~km}$, consistent with estimates from observations of total deflection beneath the Hawaiian Ridge. This suggests that coastal profiles may retain a decipherable record of sea-level change. Comparing the best-fit sea-cliff retreat rates to mean annual wave power at each site, which we calculated from $30 \mathrm{yr}$ hindcast wave data, we found a positive relationship between wave power and sea-cliff erosion, consistent with theoretical predictions and measurements on unlithified coastal bluffs. These comparisons provide field evidence that bedrock coastal erosion scales with wave power, offering a basis for modeling rocky coast evolution in different wave climates.

\section{INTRODUCTION}

Sea cliffs border $\sim 52 \%$ of the world's oceanic coastline (Young and Carilli, 2019), and their retreat threatens coastal communities and infrastructure over human time scales while also contributing substantial volumes of sediment to coastal systems and the deep ocean over geologic time scales (Covault et al., 2011). During periods of sea-level fall, sea cliffs abandoned onshore can propagate upstream as knickpoints and convey climatic and tectonic signals of sea-level change across landscapes (Mackey et al., 2014). Despite the significance of sea cliffs to landscape evolution, the rock cycle, and societal hazard, wave-induced bedrock sea-cliff erosion remains poorly quantified.

Bedrock sea cliffs erode by weathering and mass-wasting processes and by various mechanisms driven by wave attack, including impact by waves, abrasion by sediment, and plucking and quarrying of blocks (Trenhaile, 2019). Waves can also repeatedly flex sea cliffs and cause cyclic loading fatigue, potentially promoting sea-cliff erosion (Adams et al., 2005).

Because waves exert hydraulic forces on cliffs and mobilize sediment, sea-cliff erosion rates both are expected to increase with wave power and have been observed to do so in wave-tank experiments (Sunamura, 1977). Field studies have also found a positive linear relationship between wave power density (per meter of coast- line, hereafter referred to simply as wave power) and erosion rates of marsh edges and glacial till bluffs (Marani et al., 2011).

Bedrock sea-cliff erosion rates have analogously been hypothesized (Anderson et al., 1999) and indirectly observed (e.g., Quartau et al., 2010) to increase with wave power, but field studies that have attempted to quantify such a relationship have found ambiguous results. For instance, Benumof et al. (2000) found an over- riding influence of lithology on bedrock sea-cliff retreat rates in San Diego (California, USA), resulting in a spurious inverse scaling between retreat rates and wave power. Even without con- founding variables, quantifying the influence of waves on bedrock coastal erosion remains a challenge because sea-cliff erosion rates are difficult to measure over time scales relevant to coastal evolution. If mass wasting of sea cliffs occurs episodically, retreat rates measured over decadal time scales (e.g., from historic imagery) may be different than longer-term rates (Gardner et al., 1987).

Volcanic ocean islands, like the Hawaiian Islands (USA; Fig. 1A), provide an excellent opportunity to quantify the influence of waves on sea-cliff erosion because they have relatively uniform lithology but experience significant variations in wave power between sites where their shorelines face different directions and wave regimes (Fig. 1B). The age and initial topography of young volcanic islands are commonly also well constrained (Ferrier et al., 2013), so sea-cliff retreat rates 


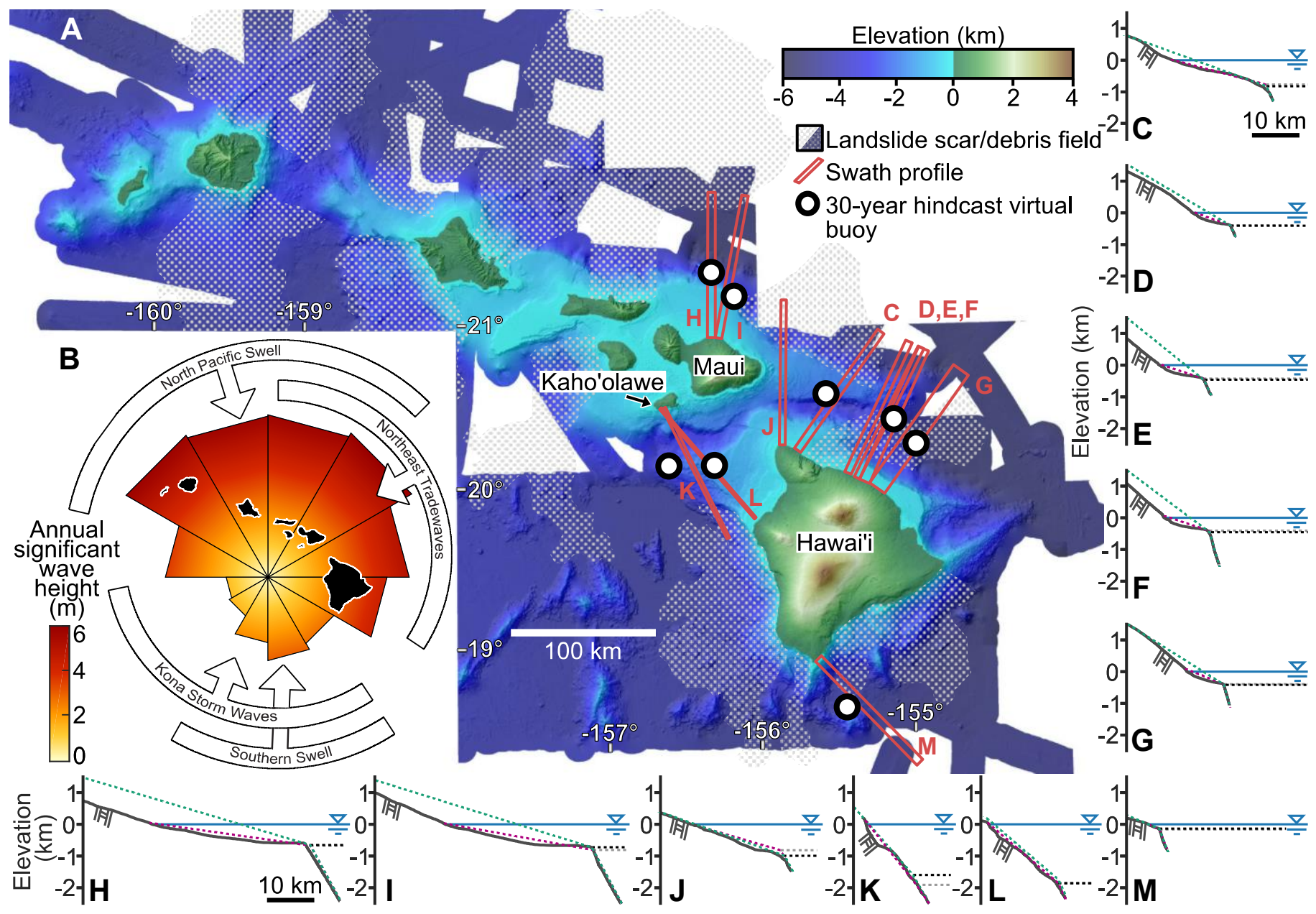

Figure 1. (A,B) Topo- bathymetry and study sites $(A)$ and wave heights and dominant wave regimes (after Vitousek and Fletcher, 2008) (B) in the Hawaiian Islands. Virtual buoys are from the U.S. Army Corps of Engineers Wave Information Studies (http:// wis.usace.army.mil/). (C-M) Swath profiles, showing mean elevation along profile (dark gray line), upper-bound and lower-bound paleoprofile reconstructions (teal and magenta dashed lines, respectively), associated slope breaks (black and light gray dashed lines, respectively), and best- fit modeled profiles (teal and magenta solid lines, respectively) for best-fit relative sea-level history with effective elastic lithospheric thickness $T_{\mathrm{e}}=30 \mathrm{~km}$ and dimensionless deflection parameter $K=-0.3$, and present-day sea level (blue line).

averaged over thousand- to million-year time scales can be estimated from island topo-bathymetry (at sites where erosion predominantly modifies the shoreline; Ramalho et al., 2013).

In this study, we examine the influence of wave power on sea-cliff retreat rates in the Hawaiian Islands. We find that the different wave regimes striking the islands' north and south shores leave a topographic signature: sea cliffs have retreated further inland where waves are larger and more frequent, etching a sea-level history in the bedrock coast.

\section{ESTIMATING SEA-CLIFF RETREAT RATES}

\section{Profile Extraction and Paleoprofile Reconstruction}

We extracted 11 cliffed coastal profiles averaged over $3-15 \mathrm{~km}$ of relatively straight coastline on the Big Island of Hawai' $i$, on Maui, and on Kaho'olawe from 3-arc-second ( $90 \mathrm{~m}$ ) U.S. National Oceanic and Atmospheric Administration (NOAA) Coastal Relief Model topo-bathymetry (National Geophysical Data Center, 2005), avoiding sites clearly affected by flank collapse, submarine landslides, or extensive coral growth (Fig. 1; Moore et al., 1994; Franklin et al., 2013). At each site, we found the mean elevations of grid points within the profile swath, binned by distance from the coast, and we linearly interpolated the resulting mean profile to evenly spaced elevation increments (Fig. 2). Each profile displays a primary submarine slope break associated with the transition from subaerial to submarine lava cooling, formed at the coast at the end of shield building (Moore and Clague, 1992). Because Hawaiian volcanoes subside millimeters per year following shield building (Huppert et al., 2015), these slope breaks are now 150 $\mathrm{m}$ to $>1500 \mathrm{~m}$ below sea level. 
We used these slope breaks to constrain the paleotopography of each site (Fig. 1; Fig. DR1 in the GSA Data Repository ${ }^{1}$ ). Specifically, we estimated a lower-bound paleoprofile as the steepest line extending from the modern sea-cliff top to the slope break and vertically bounding the bathymetry offshore, excluding any convex steps that could be coral terraces. To allow for the possibility that terrestrial processes eroded the land surface upslope of the retreating coastal cliffs, we also estimated an upper-bound paleoprofile as the steepest line vertically bounding all mean topography along the profile (which we identified by finding the convex hull of the profile; Fig. DR1). On some profiles (e.g., Fig. 1J), the paleoprofile does not intersect the observed primary slope break, so we extended the steeper slope below the slope break upward to shallower depth and found its intersection with the paleoprofile. The implied slope breaks are within the published depth range of the slope breaks mapped continuously around each volcano (Taylor, 2019).

\section{Relative Sea-Level History}

Relative sea level varies in the Hawaiian Islands due to glacio-eustatic sea-level change and uplift and subsidence of the islands in response to volcanic loading and island migration over the Hawaiian swell with Pacific plate motion. Huppert et al. (2015) filtered Hawaiian bathymetry to isolate the regional swell component, calculated the flexure resulting from loading of each Hawaiian volcano, and compared the implied vertical motions to a compilation of dated paleoshorelines. We used these constraints on island vertical motion at each site to construct site-specific relative sea-level histories for different effective elastic thicknesses of the lithosphere $\left(T_{\mathrm{e}}\right)$ and trends of deflection, prescribed by a dimensionless parameter $K(-1 \leq K \leq 1)$ that describes whether the deflection occurs early $(K>0)$, late $(K<0)$, or steadily $(K=0)$ during the growth period of each volcano (Equation DR1 in the Data Repository; Fig. 3).

\section{Sea-Cliff Erosion Model}

Numerous models have been proposed to explain the evolution of bedrock coasts (Anderson et al., 1999; Ashton et al., 2011; Trenhaile, 2019). The abundance and diversity of these models reflect the varying influences of tidal range, beach sediment, and nearshore bathymetry in different coastal settings. Because the tidal range is $<1 \mathrm{~m}$, beach sediment reservoirs are low (Fletcher et al., 2011), and nearshore bathymetry is steep at our sites compared to typical continental coast- lines, we assumed a time-invariant sea-cliff re- treat rate and removal of all bedrock undercut by sea-cliff erosion. At each site, we tested 600 retreat rates between 0.5 and $300 \mathrm{~mm} / \mathrm{yr}$ for each relative sea-level history to find the sitespecific retreat rates as well as the regionally consistent effective elastic thickness and trend of deflection during shield building that minimized the misfit (Fig. 3D) between modeled and observed coastal profiles (Figs. 1C-1M and 2B).

\section{RELATIVE SEA LEVEL IN THE HAWAIIAN ISLANDS OVER THE PAST 1.4 M.Y.}

Relative sea-level histories prescribed by $T_{e}=30 \mathrm{~km}$ and steady but increasing deflection during shield building $(K=-0.3)$ provide the best fit to the observed coastal profiles (Figs. 1C-1M and 3D). This $T_{\mathrm{e}}$ matches estimates for the Hawaiian lithosphere inferred from bathymetry, seismic reflection profiles, gravity anomalies, and dated paleoshorelines (Watts, 1978; Wessel, 1993; Huppert et al., 2015). The relatively steady trend of deflection is consistent with the time-invariant subsidence and uplift rates over the past $\sim 500$ k.y. inferred from drowned coral terraces on Hawai'i (Ludwig et al., 1991) and uplifted coral terraces on O'ahu (McMurtry et al., 2010). Our findings that this deflection increases moderately during shield building may at first seem at odds with observations of declining eruptive activity at Mauna Loa (Hawai i i). However, even if volcanism declines over shield building, consequent subsidence may be steadier in time or even progressively increasing due to a volcano's emergence above sea level (Lipman, 1995), which typically occurs about halfway through its growth period (Moore and Clague, 1992). These findings suggest that bedrock coastal profiles retain a record of relative

\footnotetext{
${ }^{1}$ GSA Data Repository item 2020144, supplementary figures, tables, and explanatory text, is available online at www.geosociety.org/pubs/ft2020.htm, or on request from editing@geosociety.org.

Huppert et al. 2020 - The influence of wave power on bedrock sea-cliff erosion in the Hawaiian Islands 
A

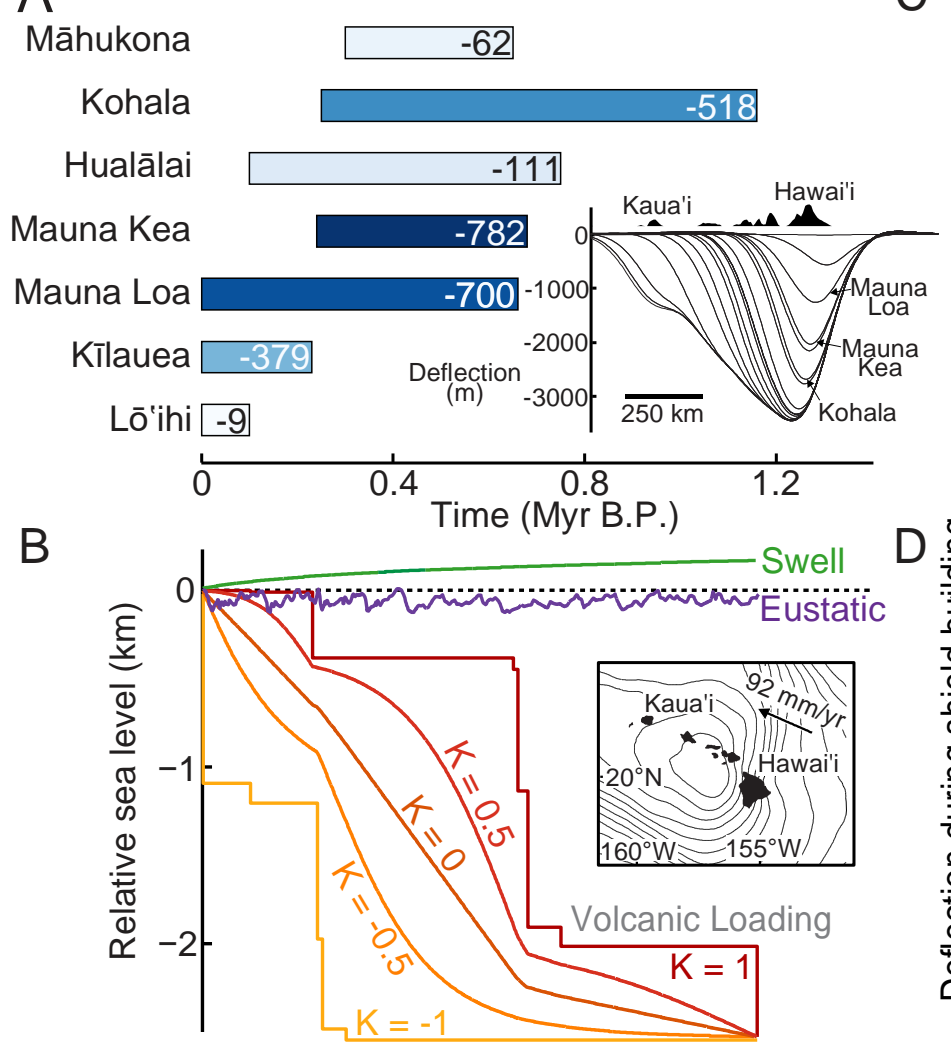



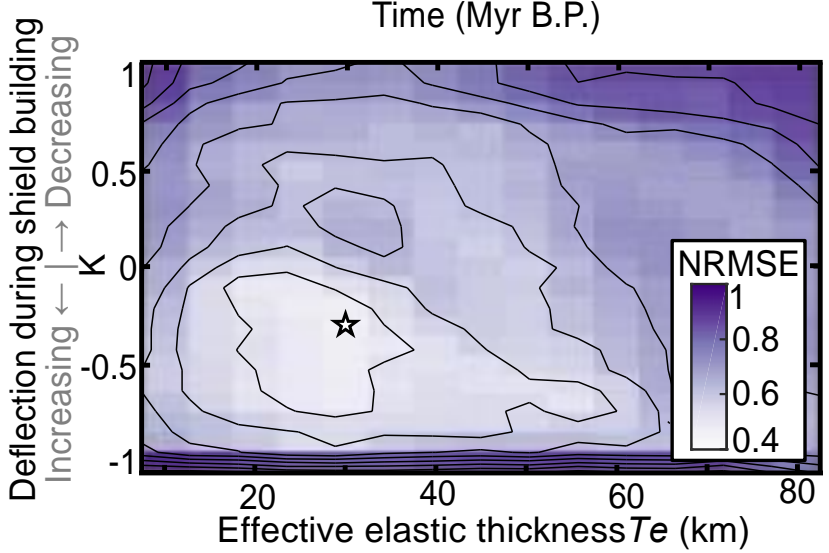

Figure 3. Relative sea level at site in Figure 2, Big Island of Hawai'i. (A) Timeline of shield-building volcanism affecting sea level at site during profile evolution (Table DR2 [see footnote 1]), colored (darker = larger magnitude) and labeled with deflection (in meters, negative for subsidence) produced at site from loading of each volcano. Inset: Deflection along the Hawaiian Ridge, infilled with deflections caused by loading of each volcano (Huppert et al., 2015). (B) Timeline of sea-level change due to eustasy (purple line; inferred from $\delta^{18} \mathrm{O}$ records; Mix et al., 1995; Lea et al., 2002), Pacific plate motion over the Hawaiian swell (green line; Huppert et al., 2015), and volcanic loading for various values of the dimensionless deflection parameter $K$ in Equation DR1 (see footnote 1). Inset: $100 \mathrm{~m}$ contour map of the Hawaiian swell with arrow showing Pacific plate motion (after Huppert et al., 2015). (C) Best-fit relative sea-level (RSL) history (gray line below and black line above slopebreak depth) for upper-bound (UB) and lower-bound (LB) paleoprofiles. Implied slope break ages are similar to the age of drowned coral terrace at a similar depth (Moore and Clague, 1992). $T_{e}-$ effective elastic lithospheric thickness. (D) Normalized root-mean-square error (NRMSE) of modeled versus observed coastal profiles for various $T_{\mathrm{e}}$ and $K$ (Equation DR1), minimized (white star) at $K=-0.3$ and $T_{\mathrm{e}}=30 \mathrm{~km}$ (used to compute deflections in A-C).

sea-level change (Adams and Limber, 2018) and independently constrain island subsidence (Quartau et al., 2014) due to volcanic loading.

\section{INFLUENCE OF WAVE POWER ON SEA-CLIFF EROSION}

For this relative sea-level history, best-fit sea-cliff retreat rates range from 17 to $118 \mathrm{~mm} / \mathrm{yr}$ at our sites. These rates are $>2 \times$ faster, on average, than rates implied by dividing the distance from the slope break to the coastline at each site. This is because the emergent sea cliff erodes only when sea level is at least as high as the modern cliff base. During periods of lower sea level, waves erode the island shelf (Mackey et al., 2014). Our analyses thus indicate that accounting for sealevel history is essential when estimating rates of coastal erosion from topo-bathymetry.

To compare these sea-cliff retreat rates to wave climate, we calculated mean annual wave power at each site from a $30 \mathrm{yr}$ record of hourly hindcast wave data reported at an array of virtual buoys surrounding the Hawaiian Islands (U.S. Army Corps of Engineers Wave Information Studies, http://wis.usace.army.mil/hindcasts. html?dmn=pacific). Mean annual wave power in the Hawaiian Islands is greatest on the northern coasts, which are impacted by large North Pacific swell waves from the northwest and smaller but persistent trade-wind waves from the north- east (Fig. 1B). These waves collectively generate $>10 \times$ as much mean annual wave power as waves from the south.

Sea-cliff retreat rates at our sites increase with mean annual wave power in deep water (Fig. 4A). We find a similar nearly linear relationship if we instead consider the lower- bound or upper-bound paleoprofile retreat rates $(E)$ individually (respectively: $E_{\mathrm{LB}} \propto P^{0.9 \pm 0.1}, R^{2}=0.95 ; E_{\mathrm{UB}} \propto P^{0.9 \pm 0.1}, R^{2}=0.87$ [ $P$ is wave power density]). Differences in mean annual Huppert et al. 2020 - The influence of wave power on bedrock sea-cliff erosion in the Hawaiian Islands 
precipitation (MAP) at the study sites (Table DR1 in the Data Repository) could perhaps explain the minor scatter in this trend $(\leq \sim 20 \%$ variability in retreat rates at a given wave power) because rainfall can promote landsliding and sea-cliff retreat (Emery and Kuhn, 1982). Sites in our study with similar wave power but higher MAP tend to have faster retreat rates $\left(E \propto\right.$ MAP $0.8 \pm 0.2, R^{2}=0.68$; PRISM Climate Group, http://www. prism.oregonstate.edu). Differences in lava-flow texture between the sites (a'ā at the Kaho'olawe and Maui sites versus both a'ā and pāhoehoe at the Big Island sites; Sherrod et al., 2007) do not appear to explain variations in sea-cliff retreat rates.

Although modern wave conditions may differ from paleo-wave conditions, waves impacting Hawai'i in the past were probably also strongly influenced by the trade winds (which have dominated regional wind patterns through Pleistocene glaciations; Ferrier et al., 2013) and Hawai'i's position within the large, swell- generating Pacific basin. Thus, we suggest that the correlation in Figure 4A most likely results from a persistent north-south dichotomy in wave power and a strong influence of waves on coastal erosion.

We also find a consistent scaling between the sea-cliff retreat rates and 1-yr-recurrence wave power, but with more scatter (Fig. 4B). The stronger correlation of the retreat rates with mean annual wave power may indicate that lower-magnitude, higher-frequency waves are the dominant agents of sea-cliff erosion at our sites. The recurrence interval of waves with power equal to the mean annual wave power ranges from 2.3 to 3.1 days. We suspect that smaller, more frequent waves are particularly effective in driving cliff retreat in Hawai'i because of the steep bathymetry and narrow or nonexistent beaches, where even small waves frequently impact the cliff face. In other settings, large storm waves may be the only waves capable of depleting beaches and reaching the cliff face. Retreat rates might also correlate more strongly with wave power generated by lower-magnitude, higher-frequency waves if repeated flexing of sea cliffs by these waves causes damage that promotes sea-cliff erosion (Adams et al., 2005).

The approximately linear relationship between wave power and bedrock sea-cliff retreat rates suggested by our observations in Hawai'i agrees with historic observations and theoretical predictions of wave-induced erosion of marsh edges and glacial till bluffs (Marani et al., 2011). Anderson et al. (1999) and other studies have assumed that bedrock sea-cliff retreat rates scale linearly with wave energy, but a positive scaling between wave power and sea-cliff retreat rates has not been observed on bedrock coasts, due largely to the difficulty of measuring bedrock sea-cliff retreat rates and controlling for lithologic variability between sites (Benumof et al., 2000). Our results provide a basis for interpreting how bedrock coasts have evolved in different wave climates and how they will respond to changing conditions. Such insight should advance efforts to account for sea-cliff sediment contributions to deep-sea reservoirs, to understand sealevel control on landscape evolution, and to infer records of sea-level change from topography.

\section{CONCLUSIONS}

The positive relationship we observe between sea-cliff retreat rates and wave power in Hawai'i provides evidence for wave-driven bed-rock sea-cliff erosion, consistent with theoretical predictions and measurements on unlithified coastal bluffs. By comparing coastal profiles developed under different sea-level histories, we obtain new constraints on the mechanical properties of the lithosphere in Hawai'i. Our analyses suggest that bedrock coastal profiles can reliably record sea level, providing a continuous data set against which to test tectonic and glacio-isostatic sea-level models. 


\section{ACKNOWLEDGMENTS}

We thank Peter Adams, Rui Quartau, and an anonymous reviewer for comments that helped improve the paper. This study was supported by the Massachusetts Institute of Technology (USA), the NEC Corporation (Japan), and NASA Headquarters under the NASA Earth and Space Science Fellowship Program, grant NNX13AN67H.

\section{REFERENCES CITED}

Adams, P.N., and Limber, P.W., 2018, Inverting shelf bedrock profiles and relative sea level rise history for paleo-wave climate: Abstract EP13A-01 presented at the American Geophysical Union 2018 Fall Meeting, Washington, D.C., 1014 December.

Adams, P.N., Storlazzi, C.D., and Anderson, R.S., 2005, Nearshore wave-induced cyclical flexing of sea cliffs: Journal of Geophysical Research, v. 110, F02002, https://doi.org/10.1029/2004JF000217.

Anderson, R.S., Densmore, A.L., and Ellis, M.A., 1999, The generation and degradation of marine terraces: Basin Research, v. 11, p. 7-19, https://doi.org/10.1046/j.1365-2117.1999.00085.x.

Ashton, A.D., Walkden, M.J.A., and Dickson, M.E., 2011, Equilibrium responses of cliffed coasts to changes in the rate of sea level rise: Marine Geology, v. 284, p. 217-229, https://doi.org/10.1016/j.margeo.2011.01.007.

Benumof, B.T., Storlazzi, C.D., Seymour, R.J., and Griggs, G.B., 2000, The relationship between incident wave energy and seacliff erosion rates: San Diego County, California: Journal of Coastal Research, v. 16, p. 1162-1178.

Covault, J.A., Romans, B.W., Graham, S.A., Fildani, A., and Hilley, G.E., 2011, Terrestrial source to deep-sea sink sediment budgets at high and low sea levels: Insights from tectonically active Southern California: Geology, v. 39, p. 619-622, https://doi.org/10.1130/G31801.1.

Emery, K.O., and Kuhn, G.G., 1982, Sea cliffs: Their processes, profiles, and classification: Geological Society of America Bulletin, v. 93, p. 644-654, https://doi.org/10.1130/0016- 7606(1982)93<644:SCTPPA>2.0.CO;2.

Ferrier, K.L., Huppert, K.L., and Perron, J.T., 2013, Climatic control of bedrock river incision: Nature, v. 496, p. 206-209, https://doi.org/10.1038/nature11982.

Fletcher, C.H., Romine, B.M., Genz, A.S., Barbee, M.M., Dyer, M., Anderson, T.R., Lim, S.C., Vitousek, S., Bochicchio, C., and Richmond, B.M., 2011, National assessment of shoreline change: Historical shoreline change in the Hawaiian Islands: U.S. Geological Survey Open-File Report 2011-1051, 55 p., https://doi.org/10.3133/ ofr20111051.

Franklin, E.C., Jokiel, P.L., and Donahue, M.J., 2013, Predictive modeling of coral distribution and abundance in the Hawaiian Islands: Marine Ecology Progress Series, v. 481, p. 121-132, https://doi.org/10.3354/meps10252.

Gardner, T.W., Jorgensen, D.W., Shuman, C., and Lemieux, C.R., 1987, Geomorphic and tectonic process rates: Effects of measured time interval: Geology, v. 15, p. 259-261, https://doi .org/10.1130/0091-7613(1987)15<259:GATPR E>2.0.CO;2.

Huppert, K.L., Royden, L.H., and Perron, J.T., 2015, Dominant influence of volcanic loading on vertical motions of the Hawaiian Islands: Earth and Planetary Science Letters, v. 418, p. 149-171, https://doi.org/10.1016/j.epsl.2015.02.027

Lea, D.W., Martin, P.A., Pak, D.K., and Spero, H.J., 2002, Reconstructing a 350 ky history of sea level using planktonic $\mathrm{Mg} / \mathrm{Ca}$ and oxygen isotope records from a Cocos Ridge core: Quaternary Science Reviews, v. 21, p. 283-293, https://doi.org/10.1016/S0277-3791(01)00081-6.

Lipman, P.W., 1995, Declining growth of Mauna Loa during the last 100,000 years: Rates of lava accumulation vs. gravitational subsidence, in Rhodes, J.M., and Lockwood, J.P., eds., Mauna Loa Revealed: Structure, Composition, History, and Hazards: American Geophysical Union Geophysical Monograph 92, p. 45-80, https://doi.org/10.1029/GM092p0045.

Ludwig, K.R., Szabo, B.J., Moore, J.G., and Simmons, K.R., 1991, Crustal subsidence rate off Hawaii determined from 234U/238U ages of drowned coral reefs: Geology, v. 19, p. 171-174, https://doi.org/10.1130/00917613(1991)019<0171:CSR OHD>2.3.CO;2.

Mackey, B.H., Scheingross, J.S., Lamb, M.P., and Farley, K.A., 2014, Knickpoint formation, rapid propagation, and landscape response following coastal cliff retreat at the last interglacial sea-level highstand: Kaua'i, Hawai'i: Geological Society of America Bulletin, v. 126, p. 925-942, https://doi.org/10.1130/B30930.1.

Marani, M., D'Alpaos, A., Lanzoni, S., and Santalucia, M., 2011, Understanding and predicting wave erosion of marsh edges: Geophysical Research Letters, v. 38, L21401, https://doi .org/10.1029/2011GL048995.

McMurtry, G.M., Campbell, J.F., Fryer, G.J., and Fietzke, J., 2010, Uplift of Oahu, Hawaii, during the past 500 k.y. as recorded by elevated reef deposits: Geology, v. 38, p. 27-30, https://doi.org/10.1130/G30378.1.

Huppert et al. 2020 - The influence of wave power on bedrock sea-cliff erosion in the Hawaiian Islands 
Mix, A., Pisias, N., Rugh, W., Wilson, J., Morey, A., and Hagelberg, T., 1995, Benthic foraminifer stable isotope record from Site 849 (0-5 Ma): Local and global climate changes, in Pisias, N.G., et al., eds., Proceedings of the Ocean Drilling Program, Scientific Results, Volume 138: College Station, Texas, Ocean Drilling Program, p. 371-412, https://doi.org/10.2973/odp.proc. sr.138.120.1995.

Moore, J.G., and Clague, D.A., 1992, Volcano growth and evolution of the island of Hawaii: Geological Society of America Bulletin, v. 104, p. 1471-1484, https://doi.org/10.1130/0016- 7606(1992)104<1471:VGAEOT>2.3.CO;2.

Moore, J.G., Normark, W.R., and Holcomb, R.T., 1994, Giant Hawaiian landslides: Annual Review of Earth and Planetary Sciences, v. 22, p. 119-144, https://doi.org/10.1146/annurev. ea.22.050194.001003.

National Geophysical Data Center, 2005, U.S. Coastal Relief Model-Hawaii: National Geophysical Data Center, NOAA, https://doi.org/10.7289/V5RF5RZZ.

Quartau, R., Trenhaile, A.S., Mitchell, N.C., and Tempera, F., 2010, Development of volcanic insular shelves: Insights from observations and modelling of Faial Island in the Azores Archipelago: Marine Geology, v. 275, p. 66-83, https://doi.org/10.1016/j.margeo.2010.04.008.

Quartau, R., Hipólito, A., Romagnoli, C., Casalbore, D., Madeira, J., Tempera, F., Roque, C., and Chiocci, F.L., 2014, The morphology of insular shelves as a key for understanding the geological evolution of volcanic islands: Insights from Terceira Island (Azores): Geochemistry Geophysics Geosystems, v. 15, p. 1801-1826, https://doi.org/10.1002/2014GC005248.

Ramalho, R.S., Quartau, R., Trenhaile, A.S., Mitch- ell, N.C., Woodroffe, C.D., and Ávila, S.P., 2013, Coastal evolution on volcanic oceanic islands: A complex interplay between volcanism, erosion, sedimentation, sea-level change and biogenic production: Earth-Science Reviews, v. 127, p. 140-170, https://doi.org/10.1016/j.earscirev.2013.10.007.

Sherrod, D.R., Sinton, J.M., Watkins, S.E., and Brunt, K.M., 2007, Geologic map of the State of Hawai'i: U.S. Geological Survey Open-File Report 2007-1089, scales 1:100,000 and 1:250,000.

Sunamura, T., 1977, A relationship between wave-induced cliff erosion and erosive force of waves: The Journal of Geology, v. 85, p. 613-618, https://doi.org/10.1086/628340.

Taylor, B., 2019, Shoreline slope breaks revise understanding of Hawaiian shield volcanoes evolution: Geochemistry Geophysics Geosystems, v. 20, p. 4025-4045, https://doi.org/10.1029/2019GC008436.

Trenhaile, A.S., 2019, Hard-rock coastal modelling: Past practice and future prospects in a changing world: Journal of Marine Science and Engineering, v. 7, 34, https://doi.org/10.3390/ jmse7020034.

Vitousek, S., and Fletcher, C.H., 2008, Maximum annually recurring wave heights in Hawai'i: Pacific Science, v. 62, p. 541-553, https://doi.org/10.2984/1534-6188(2008)62[541:MARW HI]2.0.CO;2.

Watts, A.B., 1978, An analysis of isostasy in the world's oceans 1. Hawaiian-Emperor sea- mount chain: Journal of Geophysical Research, v. 83, p. 5989-6004, https://doi.org/10.1029/JB083iB12p05989.

Wessel, P., 1993, A reexamination of the flexural deformation beneath the Hawaiian Islands: Journal of Geophysical Research, v. 98, p. 12,177-12,190, https://doi.org/10.1029/93JB00523.

Young, A.P., and Carilli, J.E., 2019, Global distribution of coastal cliffs: Earth Surface Processes and Landforms, v. 44, p. 1309-1316, https://doi.org/10.1002/esp.4574. 